\title{
Nardus stricta L. as a grassland species in the Netherlands
}

\author{
A. A. KRUIJNE \\ Institute for Biological and Chemical Research on Field Crops and Herbage, \\ Wageningen, Netherlands
}

\section{Summary}

The morphology (especially of the vegetative plant), agricultural importance and distribution of Nardus stricta L. are discussed. The most important ecological characteristics of 36 grasslands in which it occurred were investigated. It was found that Nardus occurs most frequently on very acid soils ( $\mathrm{pH}$-water: $4.05-4.50$ in the soil layer $0-5 \mathrm{~cm}$ ) and very poor soils ( $\mathrm{P}$-citric acid $\leqslant 30, \mathrm{~K}$-value $\leqslant 20$ ). This species is relatively indifferent to the degree of humidity. The sociological research comprises an investigation into the associates of Nardus on dry and moist soils.

Ten vegetations belonging to the agricultural main type Nardus stricta are briefly discussed. A survey is given of the dominance communities classified according to the $\mathrm{W} \%$ of these 10 vegetations.

\section{Introduction}

The genus Nardus of the tribus Nardae consists of the sole species Nardus stricta described by LINNAEus in 1753. Owing to the uniformity of this species few writers have been able to describe the sub-species, varieties or types. This uniformity corresponds to its isolated place in the phytogenetic system of gramineous plants, and it is this very isolation that creates doubt as to its place.

Nardus stricta has been considerably reduced by reclamation and grassland improvement, so that this unproductive grass species is no source of trouble in the Netherlands. For Dutch grasslands a closer consideration of the ecology and sociology of this species, now becoming rare, is of historical interest only. Nevertheless, the following is of topical interest in countries where the species is still abundant.

\section{General data}

2.1. Morphology (FIG. 1)

Nardus stricta is a perennial. The spikelets, stalkless and 1-flowered, are in two rows along one side of the axis. The glumes are very small, the upper ones often absent. The 3-nerved lemma is acuminate or tipped with a short awn. It is longer than the 2-nerved palea, which is awnless. There are three stamens and one style. The species flowers in May-July. The leaves are folded like bristles and the somewhat rough, mature leaves are almost rectangularly extended; the ligule is $11 / 2 \mathrm{~mm}$ and well visible. These characteristics distinguish the species from its associates, which it may resemble in the vegetative stage, e.g. Corynephorus canescens P.B., Deschampsia flexuosa TriN., Festuca ovina $\mathrm{L}$. and Festuca rubra $\mathrm{L}$.

Received for publication 30th December, 1964. 
According to some writers the species has a rhizome (JefFries, 1917; HubB Ard, 1954). However, the growth habit suggests a considerable functional difference between this organ and the rhizomes as found on Elytrigia repens NevsKI and Holcus mollis $\mathbf{L}$. Closer inspection proved that the rhizome of Nardus stricta showed neither the rapid growth nor the extravaginal branching common in grasses. Consequently it plays no active part in the spreading of the species. The complete organ closely resembles a comb with upright teeth (shoots). The old shoots die on one side of the "rhizome", and on the other a bud develops inside the leaf-sheath of the young shoot (intravaginally), as a result of which the shoots grow closely together in a row. Growth of the "rhizome" is slight and only amounts to a few $\mathrm{cm}$ a year.

The base of the shoots is enclosed by strong, straw-coloured sheaths, which are much flattened, carrying a rudimentary leaf-blade in the form of a hardly perceptible tip. The younger sheaths growing inside these basal sheaths closely approximate the normal length: width proportion. On the tip they carry a reduced leaf-blade of about $3 \mathrm{~mm}$, which already shows the perpendicular habit of the normally developed leaves. This is characteristic for this species. These reduced leaf-blades are best observed by holding a tuft of shoots against the light, when it seems as though the alternate arrangement of the successive leaf-sheaths (differing $180^{\circ}$ in insertion) is not maintained. However, closer inspection reveals an undeveloped leaf-sheath in between, restoring the regular order of the alternate arrangement. Sometimes the sheaths are somewhat twisted with regard to each other, so that the irregularity is only apparent.

\subsection{Agricultural importance}

In the Netherlands Nardus stricta is considered a very inferior species; its valuation number is 0 (DE VRIES, 'T HART and KRUIJNE, 1942). It is a tough, wiry grass with a very low productivity. Sheep and sometimes also cattle, only feed on this grass when it is in the young stage, and even then reluctantly. It is recommended to interrupt sheep grazing during the winter months, as the spring growth will be more appreciated owing to the higher percentage of young material.

Tufts, sometimes in great numbers, can often be pulled off the old plants. After these tufts have withered the land presents an untidy appearance. It is suggested that livestock pull up these tufts in search of more palatable fodder.

In Alpine pastures Nardus often reaches absolute dominance. As it is the only fodder plant available there, livestock seems to feed on it reasonably well. It is unaffected by grazing or treading.

\subsection{Geographical distribution}

Nardus stricta is distributed throughout Europe and temperate Asia; its distribution approaches the Arctic Circle. In the Alps it grows up to $3000 \mathrm{~m}$, and in North Africa (Atlas Mountains) as high as $3500 \mathrm{~m}$. The species occurs in the Azores and Greenland and has been introduced into many parts of Canada, North America and Tasmania. In the Netherlands it mainly occurs in the eastern part of the country and on some dune sands.

\section{Method of research}

The investigation into the ecology of Nardus stricta as a grassland plant only constitutes a very small part of the correlative-ecological research into Dutch grasslands. 
FIg. 1. Nardus stricta L. A. flowering plant $(3 / 4 \times)$; B. leaf in cross section $(15 \times)$; C. leaf-base with ligule $(3 \times)$; D. part of the ear $(11 / 2 \times)$; E. (left) lemma, (right) palea $\left(1 \frac{1 / 2}{2}\right)$; F. two tillers with basal leaf-sheaths and, in the centre, the reduced leaf-blades $\left(1 \frac{1}{2} \times\right)$

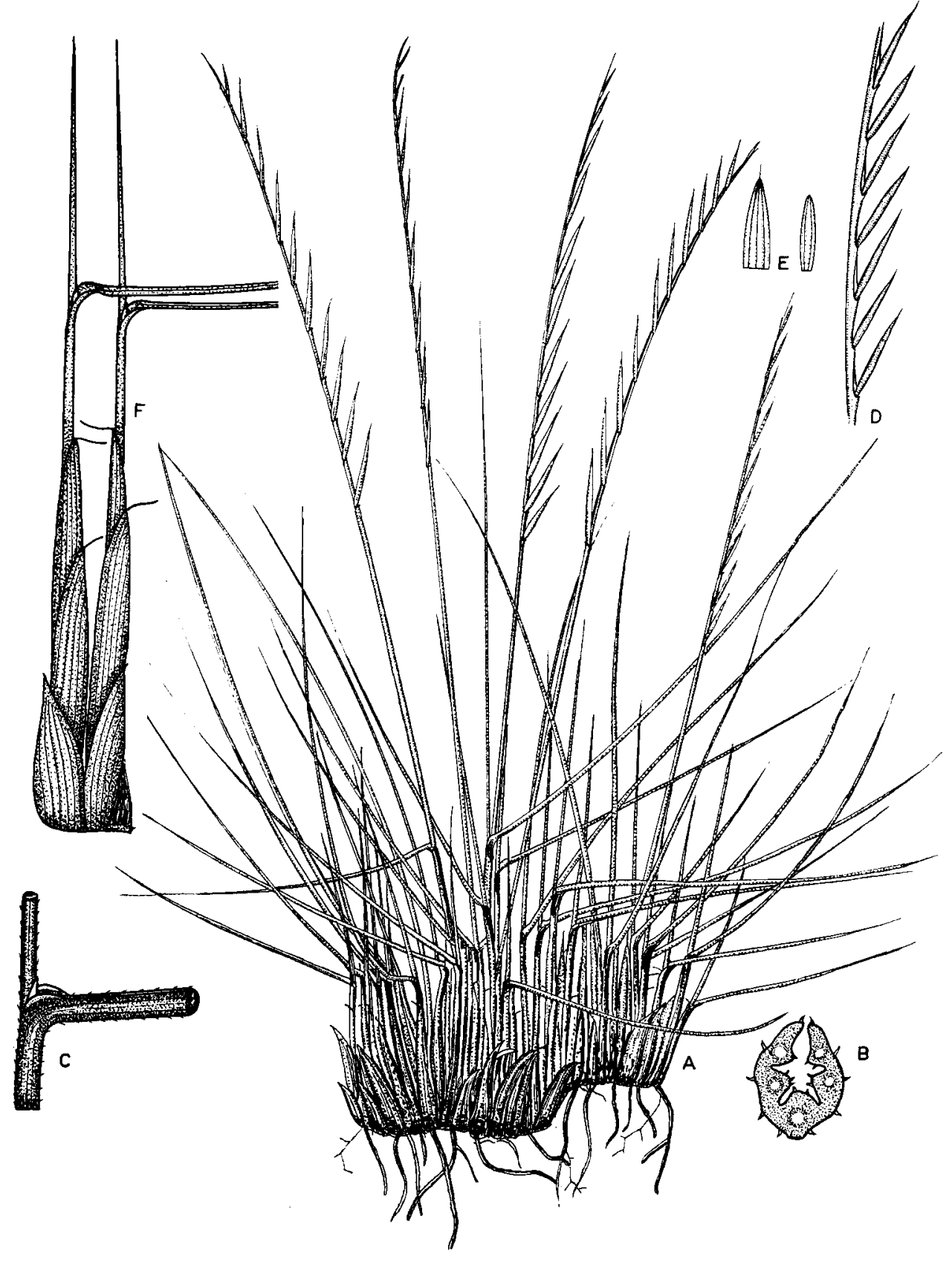



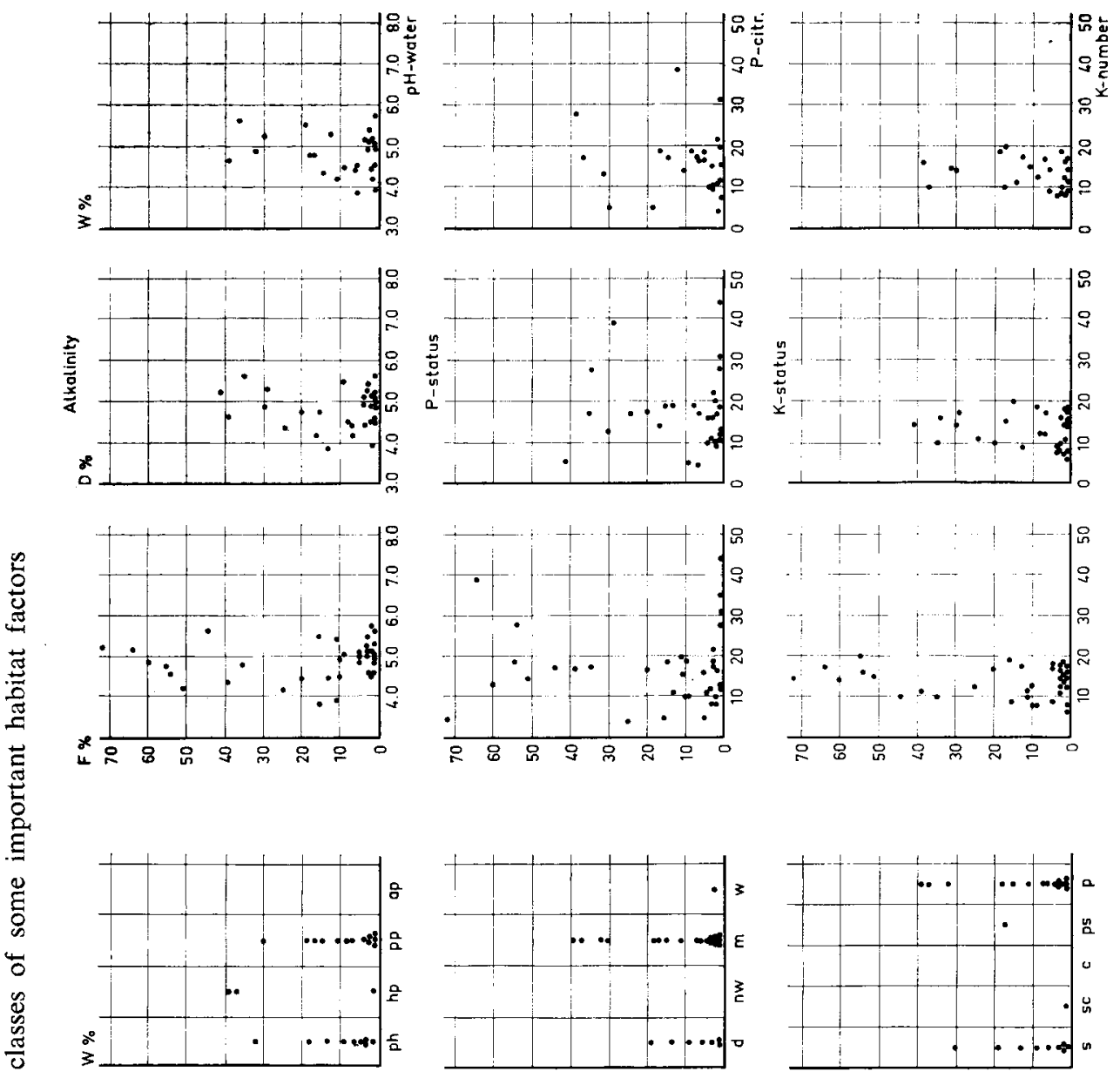

$\stackrel{8}{\Xi}$

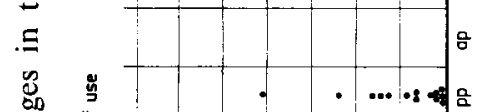
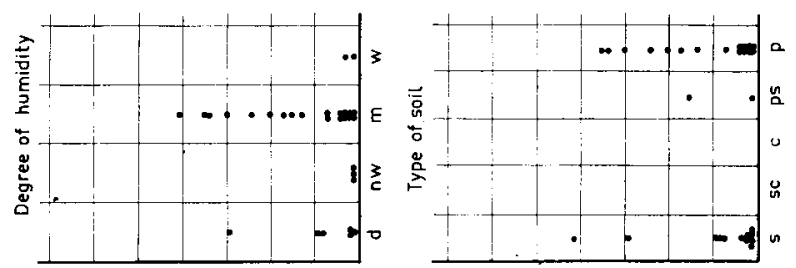

홍

ค

I"

i

I
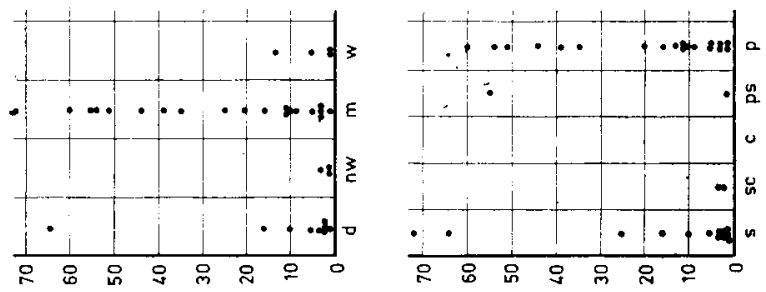
This research with DE VRIES (1957) as mentor, covered 1577 fields distributed throughout the Netherlands (KRUIJNe, DE VRIES and Moor, in manuscript). Per field an average of 10025 sq.cm borings were botanically analysed by making a complete record of species (DE VRIES, 1937). The following was found for each field:

a. the frequency percentage (F \%) of each species, i.e. the percentage of borings in which the species is present;

b. the dominance percentage (D \%) of each species, indicating the percentage of borings in which the species occupies the first place after a visual mass comparison;

c. the weight percentages $(\mathrm{W} \%)$ of each species, i.e. the percentage by weight of each species in the air-dry material of a composite sample. Calculation of the grade of quality $(\mathrm{Gq})$ of the crop is based on the W\% of the species (DE VRIES, 'T HART and KRUIJNe, 1942).

In addition to the botanical sample a soil sample was taken of the layer $0-5 \mathrm{~cm}$, which was analysed for soil type, alkalinity, P-status and K-status. Information provided by the farmer and field observations supplied sufficient data on the use and general moisture condition of the field.

To determine the ecology of the species the F \%, D \% and $\mathrm{W} \%$ were examined in the various habitat-factor classes; the type of use and degree of humidity were divided into four classes each, the soil type into five: -

a. type of use: $\mathrm{ph}=$ pure hayfield, $\mathrm{hp}=$ hay pasture, $\mathrm{pp}=$ pure pasture, very extensively used and ap = alternate pasture, intensively used,

b. degree of humidity: $\mathrm{d}=$ dry, $\mathrm{nm}=$ normal moisture content, $\mathrm{m}=$ moist, $\mathrm{w}=$ wet,

c. soil type: $s=$ sand $(0-10 \%$ silt fraction $)$, sc $=$ sandy clay $(11-40 \%$ silt fraction), $\mathrm{c}=$ clay $(>40 \%$ silt fraction), $\mathrm{ps}=$ peaty soil $(21-30 \%$ humus $), \mathrm{p}=$ peat ( $>30 \%$ humus).

The remaining soil factors are expressed as follows: -

d. alkalinity: pH-water,

e. P-status: $\mathrm{mg}$ of $\mathrm{P}_{2} \mathrm{O}_{5}$ per $100 \mathrm{~g}$ of air-dry soil, determined after one extraction with $1 \%$ citric acid,

f. K-status: the amount of $\mathrm{K}_{2} \mathrm{O}$, determined for sand and sandy clay soil, but calculated for the heavier soils, after one extraction with hydrochloric acid. One unit $=0.09 \mathrm{~g}$ of $\mathrm{K}_{2} \mathrm{O}$ per $1000 \mathrm{~g}$ of humus.

The sociology, to a certain extent agriculturally focussed, may be determined from the botanical analysis.

\section{Results}

\subsection{General results}

Nardus stricta was found in 36 fields out of 1577 , i.e. in $2.4 \%$ of the fields. The species was present in 650 borings out of 157,700 (an average of 100 borings per field), so that the average $F \%$ was 0.4 . It dominated in 321 borings: an average D \% of 0.2. The dominance tendency (DE VRIEs and Hoogers, 1959) was: $100 \Sigma \mathrm{D}$ : $\Sigma F=32100: 650=49$, a figure higher than any other mentioned in that paper, indicating a high degree of tuft-formation, leaving hardly any room for other species. The average $\mathrm{W} \%$ was also 0.2 .

It should be realized that the research, on which these figures are based was started as early as 1935 and continued for approximately 25 years. The values of the average $\mathrm{F} \%, \mathrm{D} \%$ and $\mathrm{W} \%$ are much lower for the present-day grasslands.

Neth. J. agric. Sci., Vol. 13 (1965) No. 2 (June) 


\subsection{Ecological results}

In FIG. 2 the F \%, D \% and W \% of each of the 36 fields in which Nardus stricta was found are arranged according to the various habitat factors. It was assumed that high $\mathrm{F} \%$ 's, and especially high $\mathrm{D} \%$ 's and $\mathrm{W} \%$ 's, indicate the suitability of the habitat for Nardus. Less favourable habitat factors are primarily expressed in reduced dominance and a lower weight share of the species.

Obviously many habitat factors are closely correlated, as indicated by the following survey of the ecology of Nardus.

\subsubsection{Type of use}

The type of use does not affect the occurrence of Nardus stricta; the D \%'s and W \%'s clearly indicate this. It should be realized, however, that grazing in general is very slight. The fields classified as pure pastures were very extensively grazed and could not be compared with the well-fertilized and intensively grazed pure pastures distributed throughout the country.

Nardus is not found on the alternate pastures needing deliberate management. As in practice increased grazing and fertilization are correlated, this means that on more intensively-used fields this species cannot compete with the surrounding vigorously growing herbage plants.

\subsubsection{Degree of humidity}

Nardus stricta is found in all four classes, but most frequently in the "dry" and "moist" classes. In the two other classes the F \%, and especially the D \% and $\mathrm{W} \%$, remain low. As for the class "wet", the high moisture degree has an immediate adverse effect. This class comprises many exclusively hayed and therefore poor fields, generally favourable for this species. In agreement with the preceding JeFFrIEs (1917) found that when Nardus grows on soils inundated in winter it dies almost completely and is replaced by Molinia caerulea MoENCH, for example. An immediate adverse effect cannot be shown for the "normal moisture content" class which is intermediate between the "dry" and "moist" classes. Probably this is again caused by intensive use, and is closely related to improved fertilization on many fields in this class.

A wide humidity range is relatively rare for a plant species. De Coulon (1923) described two anatomically different root types, one of a hygrophilous and one of a xerophilous kind. Usually, both kinds are present in a Nardus plant, but the moisture degree of the habitat apparently affects the development of one kind more than the other. De Coulon has recorded that xerophilous roots do not develop in water cultures. It seems plausible that these two kinds of root enable the plant to adjust itself better to the soil-moisture content.

This soil-moisture content is also considered in the sociological investigation.

\subsubsection{Soil type}

Nardus stricta was found on all soil types except clay. It clearly prefers sand and peat soils, corresponding to its preference for dry soils on the one hand, and moist soils on the other. Its infrequent occurrence on sandy clay soil and absence on clay soil is probably due to the inherent fertility of these soils and consequently their more intensive use.

\subsubsection{Alkalinity}

Nardus stricta occurs almost exclusively in the pH-range 4.00-5.50, viz. in the agriculturally very acid and moderately acid areas. It was not found in areas with a pH 
of over 5.75. According to CHADwICK (1960) it is neither found on the more calcareous soils in England. According to KLAPP (1941) it only occurs on these soils if there is a humic layer. However, local leaching on calcareous soils (decreasing $\mathrm{pH}$ ) may also create a favourable habitat.

\subsubsection{P-status}

Nardus stricta is not found on soils with a sufficient to good P-status. Most of the fields on which the species occurs have a P-citric number below 20.

\subsubsection{K-status}

Nardus stricta does not occur on fields with a $\mathrm{K}$-value of over 20 . Although agriculturally this limit is considered fairly low, the K-status of some fields with a high humus content may be classified as "fairly high".

This ecological survey shows that this species can be eliminated and better grass species stimulated by liming and applying $\mathbf{P}, \mathrm{K}$, (and N) fertilizers. Moreover, improved grazing, or cutting a few times a year, will stimulate the vegetation in the same way. Nevertheless it may take a very long time to eliminate Nardus, especially from fields in which it is dominant.

KLAPP (1941) even suggests ploughing up such vegetations as occur on Alpine pastures, and improving the soil by the application of lime and fertilizers to permit the establishment of better grasses.

Chadwick (1960) mentions a few more conditions limiting the occurrence of Nardus stricta: the species does not occur (in England) if annual rainfall is below $508 \mathrm{~mm}$ (20 inches); moreover, it cannot tolerate shade.

\subsection{Soc iological results}

With the sampling method employed in the present study it was impossible to determine a sociological group of plants similar to that obtained, for example by the Braun-Blanquet method. If the whole area sampled (averaging $1 \mathrm{ha}$ ) is to be considered, the heterogeneity of the soil and consequently that of the vegetation will be very important. For instance, on field 772 (F \% of Nardus $=64$ ), classified as moist throughout, such drought-resistant species as Galium hercynicum WeIG., Stellaria graminea L. and Hieracium pilosella L. were found, whereas aquatic species like Equisetum fluviatile L. and Eriophorum species were found on the dry field 1530 (F \% = 72).

The fact that Nardus stricta is relatively ,little affected by the degree of humidity is manifested in two more or less different groups of associates. In order to identify these groups, all borings from dry and moist fields containing Nardus stricta were separately analysed to determine the species occurring in the same small area of 25 sq. cm (TABle 1). There are three different groups, viz. one group of species associated with Nardus in moist areas only; a group associated with Nardus in the dry areas only and one group, like Nardus, which is not affected by the degree of humidity and may be found anywhere.

All these species are also found in records obtained by other methods, not limited to grassland (Preising, 1950; Chadwick, 1960).

In 10 field samples out of 36 in which Nardus stricta was found, its F \% was 25 or over. According to the agricultural classification of DE VRIEs (1948), these vegetations belong to the main type Nardus stricta. A reasonably good differentiation of 
TABLE 1. Nardus stricta associates on moist and dry fields (occurrence $5 \%$ or more); see text on p. 175

\begin{tabular}{|c|c|c|}
\hline & Moist & Dry \\
\hline Molinia caerulea MOENCH & 54 & $\mathbf{0}$ \\
\hline Potentilla erecta RÄUSCHEL $\ldots \ldots \ldots \ldots \ldots \ldots$ & 51 & 0 \\
\hline 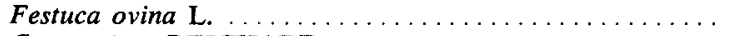 & 32 & $\mathbf{0}$ \\
\hline Carex nigra REICHARD .... & 19 & 0 \\
\hline Erica tetralix $\mathbf{L} . \ldots \ldots \ldots \ldots \ldots \ldots \ldots \ldots \ldots \ldots \ldots$ & 18 & $\mathbf{0}$ \\
\hline Carex panicea $\mathbf{L} . \quad \ldots \ldots \ldots \ldots \ldots \ldots \ldots$ & 17 & $\mathbf{0}$ \\
\hline 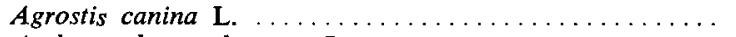 & 42 & 10 \\
\hline Anthoxanthum odoratum $\mathrm{L} . \ldots \ldots \ldots \ldots \ldots \ldots \ldots$ & 26 & 31 . \\
\hline$\ldots \ldots \ldots \ldots \ldots \ldots \ldots$ & 15 & 35 \\
\hline Sieglingia decumbens BERNH. $\ldots \ldots \ldots \ldots \ldots \ldots \ldots$ & 12 & 23 \\
\hline 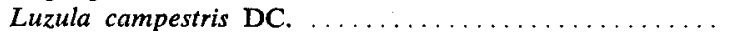 & 11 & 55 \\
\hline$\ldots \ldots \ldots \ldots \ldots \ldots \ldots \ldots$ & 7 & 26 \\
\hline$\ldots \ldots \ldots \ldots \ldots \ldots \ldots$ & 0 & 33 \\
\hline Rumex acetosella $\mathrm{L}$. & 0 & 16 \\
\hline$\ldots \ldots \ldots \ldots \ldots \ldots \ldots, \ldots$ & 0 & 14 \\
\hline
\end{tabular}

description and evaluation within related vegetations is obtained by distinguishing another type-representative species and possibly a minor-type representative.

In practice it is important to know the species making up the bulk of the vegetation (according to the $\mathrm{W} \%$ ) at the time of sampling. This is indicated by estimating the association of the leading species (dominance community) according to the following degrees of purity: -

a. very pure: $\mathrm{W} \%$ of the dominant is over 50 (designated, e.g. A (= symbol denoting plant species) or species name (underlined);

b. pure: $W \%$ of the dominant is 25 or over (designated $A$ );

c. mixed: besides the dominant one or two other species with a $W \%$ of 25 or over (designated $\mathbf{A} \times \mathbf{B})$;

d. impure: $\mathrm{W} \%$ of the dominant is below 25 ; together with another species 25 or over (designated $\mathbf{A}+\mathbf{B}$; if both species have the same percentage $\mathbf{A}+\mathbf{B}$ ).

The last-mentioned is shown in TABLE 2 .

TABLE 2. Survey of the agricultural classification, dominance community and grade of quality of the 10 vegetations belonging to the main type Nardus stricta

Agricultural

classification

1. $\mathbf{N}-\mathbf{M}$

2. $N \rightarrow M$

3. $\mathbf{N}-\mathbf{M}-\mathbf{A c} \ldots \ldots \ldots \ldots$

4. $\mathbf{N}-\mathbf{M}-\mathbf{F o} \ldots \ldots \ldots \ldots$

5. $\mathbf{N}-\mathbf{M}-\mathbf{F o} \ldots \ldots \ldots \ldots$

6. $\mathbf{N}-\mathbf{M}-\mathbf{F o}, \ldots \ldots \ldots \ldots$

7. $\mathbf{N}-\mathbf{M}$ - Fo $\ldots \ldots \ldots \ldots$

8. $\mathbf{N}-\mathbf{A c} \ldots \ldots \ldots \ldots \ldots \ldots$

9. $\mathbf{N}-\mathbf{A c}-$ Ao $\ldots \ldots \ldots \ldots$.

10. $\mathbf{N}-$ Ao - Fr $\ldots \ldots \ldots$
Dominance
community

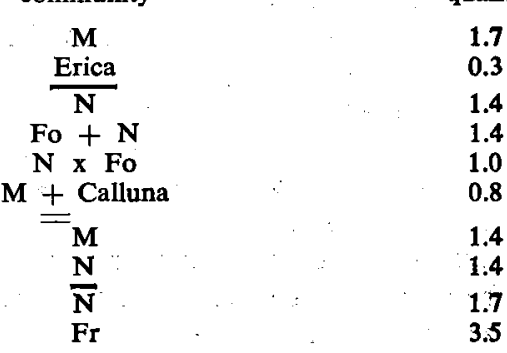

Ac = Agrostis canina L., Ao = Anthoxanthum odoratum L., Calluna = Calluna vulgaris HULL, Erica =Erica tetralix L., Fo = Festuca ovina L., Fr = Festuca rubra L., M = Molinia caerulea MOENCH, $\mathbf{N}=$ Nardus stricta $\mathbf{L}$. 
Brief agricultural-ecological descriptions of the three grassland types as mentioned in TABLE 2 are as follows:

1-7: Nardus stricta - Molinia caerulea, grasslands on very poor, acid and moist to temporary wet soils, used as hayfields, or rarely, and in such cases extensively. grazed,

8-9: Nardus stricta - Agrostis canina, grasslands similar to the preceding ones, but rather more often grazed and somewhat more fertile,

10: Nardus stricta - Anthoxanthum odoratum, grasslands with an insufficient fertilization status, but more fertile than the preceding ones and in particular less moist.

Of the remaining 26 samples with Nardus stricta, not belonging to this main type, the numbers mentioned were found to belong to the following main types: 11 Molinia caerulea, 6 Festuca rubra, 4 Festuca ovina, 2 Agrostis canina, 1 Anthoxanthum odoratum, 1 Agrostis tenuis and 1 Poa trivialis. All these grassland types are poor to insufficient except that of Poa trivialis. Generally, the latter type is considered to be sufficient to good, but in this case it is not up to this valuation $(\mathrm{Gq}=4.6$, dominance community: Anthoxanthum odoratum). This is a moist hay pasture on sand which is poor and acid and certainly affords Nardus every opportunity to occur.

Chadwick, M. J.

COULON, J. DE

HUBBARD, C. E.

JEFFRIES, $\mathrm{H}$.

KLAPP, E.

KruiJne, A. A., D. M. DE

VRIES and H. Moor

Preising, E.

VRIES, D. M. DE

M. L. 'T HART

and A. A. KRUIJNe

and B. J. HOOGERS

\section{REF E R E NCES}

1960 Nardus stricta L. J. Ecol. 48, 255-267.

1923 Nardus stricta L. Mem. Soc. Vaud. Sci. Nat. 6, 245-332.

1954 Grasses. Penguin Books No. A 295, 428 pp.

1917 The vegetation of four Durham Coalmeasure fells. II. Water supply and other ecological factors. J. Ecol. 5, 129-154.

1941 Taschenbuch der Gräser. Verlag Paul Parey, Berlin, 163 pp. Bijdrage tot de oecologie der Nederlandse graslandplanten (in manuscript).

1950 Nordwestdeutsche Borstgras-Gesellschaften. Mitt. Flo.-Soc. Arb. gem. 1950. H 2, 33-42.

1937 Methods used in scientific plant sociology and in agricultural botanical grassland research. Herb. Rev. 5, 187-193.

1948 Method and survey of the characterization of Dutch grasslands. Vegetatio. 1, 51-57.

1957 Overzicht van de ontwikkeling van het botanische graslandonderzoek in Nederland. Jaarb. I.B.S. 1957, Wageningen. $171-181$.

1942 Een waardering van grasland op grond van de plantkundige samenstelling. Landbk. Tijdschr. 54, 245-265.

1959 Distribution of tillers of plant species in old permanent grassland with different types of use. Neth. J. Agric. Sci. 7, 232236. 